\title{
Farlig tiltrekning
}
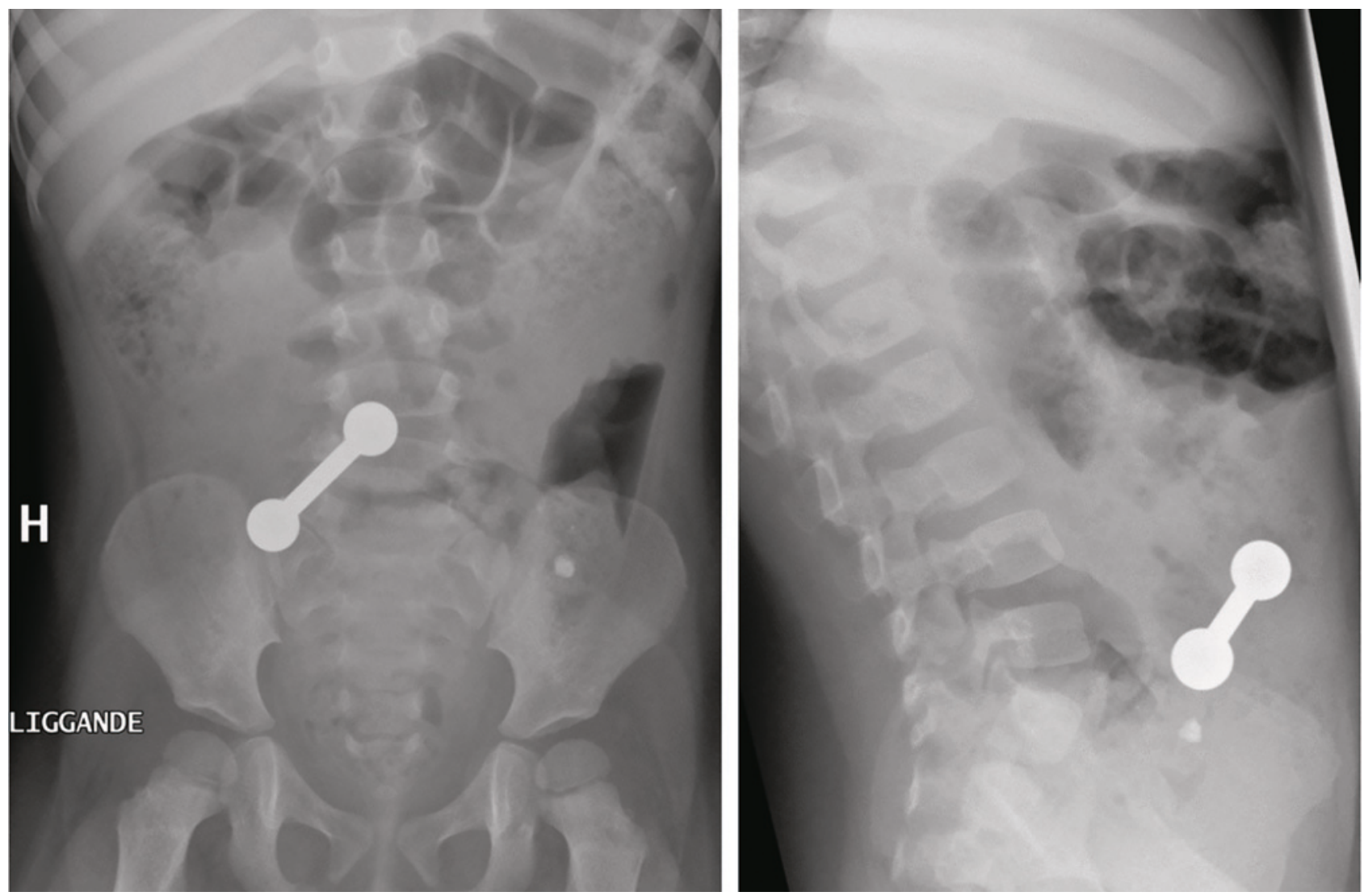

En to og et halvt år gammel jente ble innlagt i barneavdeling fra legevakt etter 12 timers sykehistorie med smerter i magen og oppkast. Ved innkomst var hun slapp og i noe redusert allmenntilstand, men godt sirkulert, med pulsfrekvens på 136 per minutt. Respirasjonen var ubesvært. Buken var lett øm, men ikke peritonittisk.

Det ble gjort ultralyd abdomen, som viste et fremmedlegeme $\mathrm{i}$ tarmen. Røntgen oversikt abdomen viste et $1,5 \times 5,5 \mathrm{~cm}$ røntgentett fremmedlegeme formet som en pinne med en kule i hver ende. Foreldrene husket etter hvert at barnet fire måneder i forveien hadde spist tre magnetleker. De hadde regnet med at lekene ville passere.

Jenta ble laparotomert, og man fant intraoperativt to magneter i ileum som hang sammen over tarmveggen med en magnet $i$ sigmoideum. Det hadde dannet seg en ileosigmoidal fistel. Magnetene ble fjernet og fistelen lukket. Det postoperative forløpet var ukomplisert.

Svelging av magneter eller én magnet og metallbiter kan være farlig, fordi de kan tiltrekkes av hverandre fra forskjellige tarm- avsnitt over tarmveggen. Det er beskrevet perforasjoner, fistler og volvolus forårsaket av svelgede magneter. Magnetene bør, hvis mulig, hentes ut endoskopisk (1). Problemet er sannsynligvis økende, fordi magnetisk leketøy er blitt populært (2).

Pasientens foreldre har gitt samtykke til at artikkelen blir publisert.

\section{Wenche Marie Fjeldsbø}

Barneklinikken

\section{Stein Magnus Aukland}

Radiologisk avdeling

\section{Erling Tjora}

erling.tjora@helse-bergen.no

Barneklinikken

Haukeland universitetssykehus

Wenche Marie Fjeldsbø (f. 1966) er lege i spesialisering i voksenpsykiatri og i barne- og ungdomspsykiatri og for tiden i sideutdanning ved Barneklinikken

Forfatter har fylt ut ICMJE-skjemaet og oppgir ingen interessekonflikter.
Stein Magnus Aukland (f. 1967) er ph.d., spesialist i radiologi og overlege ved Seksjon for barn. Forfatter har fylt ut ICMJE-skjemaet og oppgir ingen interessekonflikter.

Erling Tjora (f. 1972) er ph.d., spesialist i barnesykdommer og overlege ved Seksjon for gastroenterologi og ernæring.

Forfatter har fylt ut ICMJE-skjemaet og oppgir ingen interessekonflikter.

\section{Litteratur}

1. Hussain SZ, Bousvaros A, Gilger M et al. Management of ingested magnets in children. J Pediatr Gastroenterol Nutr 2012; 55: 239-42.

2. Brown JC, Otjen JP, Drugas GT. Too attractive: the growing problem of magnet ingestions in children. Pediatr Emerg Care 2013; 29: 1170-4.

Mottatt 4.2. 2014, første revisjon innsendt 16.4 . 2014, godkjent 23.4. 2014. Redaktør: Tor Rosness. 